\title{
Evaluation of Interleukin-17 in Viral Warts
}

\author{
Osama H. Alkady ${ }^{\text {a }}$, Soha E. Abduulah ${ }^{\text {b }}$, Yasser M. Ismail ${ }^{\text {c }}$, Shymaa M. Rezk ${ }^{\text {a }}$
}

$\mathbf{a}$

Department of Dermatology, Venereology and Andrology, Faculty of Medicine, Benha University, Egypt. ${ }^{\mathrm{b}}$ Department of Dermatology, Venereology and Andrology $6^{\text {th }}$ October University, Egypt. ${ }^{\mathrm{c}}$ Department of clinical pathology, Faculty of Medicine, Benha University, Egypt.

Correspondence to: Soha E. Abduulah, Department of Dermatology, Venereology and Andrology $\quad, \quad 6^{\text {th }}$ October University, Egypt

Email:

sohaelsayed54@gmail.com

Received: 1 September 2020

Accepted: 27 October 2020

\begin{abstract}
:
Background: Warts are common benign epithelial keratinocytes proliferations caused by human papillomavirus (HPV) infection that may involve the skin and the mucous membranes Interleukin-17A (IL-17A), is a prototypic member of cytokines. It is recognized as an inflammatory cytokine and exerts its function mainly on myeloid cells and mesenchymal cells to induce the expression of certain kinds of chemokines, which in turn increase granulopoiesis and recruit neutrophils to the infectious site. Aim and objectives: The aim of the work was to evaluate the serum level of interleukin 17 in patients with viral warts and its correlation with the disease severity. Subjects and methods: this was a case control study, in which participants were selected from the outpatient clinic of Dermatology, Venereology \& Andrology department of Benha University Hospitals, carried on sixty patients of wart and thirty healthy subjects serving as a matched control subjects group. Serum IL17 was detected by ELISA Results: The results of the study revealed that there was high statistically significant difference between groups regarding IL 17 serum level where it was higher
\end{abstract} with warts irrespective of their clinical type (plane, plantar or common). This finding may denote that IL17 may have a role in pathogenesis of viral warts.

Keywords:Warts,Interleukin17,IL17

\section{Introduction}

Warts are common benign epithelial keratinocytes proliferations caused by human papillomavirus (HPV) infection that may involve the skin and the mucous membranes. Warts are typically small, rough, and hard growths that are similar in 
colour to the rest of the skin. They typically do not result in other symptoms, except when on the bottom of the feet where they may be painful. Although, they usually occur on the hands and feet they can also affect other locations (1). Interleukin-17A (IL-17A), discovered in 1993, is a prototypic member of 18 cytokines (2). It is recognized as an inflammatory cytokine and exerts its functions mainly on myeloid cells and mesenchymal cells to induce the expression of certain kinds of chemokines, which in turn increase granulopoiesis and recruit neutrophils to the infectious site. However, It was originally thought to be of minimal importance because it lacks immediate effects on T and B cells (3).

Low IL-17 levels may contribute in occurrence, maintenance, severity, and recurrence of different types of cutaneous wart that depend mainly on the cellmediated immunity defect (4).

The aim of this study was to evaluate the possible role of serum IL17 in the pathogenesis of viral warts by measuring its level in the serum of warts' patients and to correlate its level with the disease severity.

\section{Subjects and Methods}

\section{The Study Population}

This was a case-control study. The current study was conducted in Dermatology,
Venereology \&Andrology department of Benha University Hospitals, at Benha city, Egypt, during the period of September 2018 to April 2019. The study included sixty patients with warts and 30 healthy, age and sex matched controls. Participants gave their informed written consent before enrolment and the study was approved by the Research Ethics Committee in Faculty of Medicine, Benha University.

All patients enrolled in the study had viral warts. Both sexes were involved in the study. Patients with skin diseases other than warts and subjects with acute or chronic infections, malignancies, autoimmune disorders, hepatic or renal diseases were excluded. None of the patients was on systemic or topical treatment for one month before the study. Warts were diagnosed clinically.

Personal, family and past histories were taken. General (height, weight and blood pressure) and dermatological examination (site, type and number of warts ) were also done .

\section{Assessment of serum level of Interleukin}

\section{7:}

Five $\mathrm{ml}$ blood sample were collected from each individual under aseptic condition by clean venepuncture 
- Blood sample was kept in a sterile plain tube. The blood was left to clot at $37^{\circ} \mathrm{C}$ and then stored at $-20^{\circ} \mathrm{C}$ for assessment of serum IL 17. The kit used was a doubleantibody sandwich enzyme-linked immunosorbent assay (ELISA) to assay the level of Human Interleukin 17 (IL-17) in samples.IL-17 were measured using their commercially available kits (Human IL-17 ELISA kit ) which were provided by Sunredbio (Tel (86-21-51877391), Fax : (86-21-51564103), Address: Room 212, MeiLan Building, NO.6497Hu Tai Road . Baoshan District, Shanghai).

Assay range for IL-17 : (15 pg/ml- 1000 $\mathrm{pg} / \mathrm{ml})$

\section{Statistical Analysis}

Statistical analysis was performed using the Chi-square test, Monte Carlo correction Student t-test, Mann Whitney test, Kruskal Wallis test and Spearman coefficient. This was done using Statistical package for social science program for windows (SPSS) version 22 (SPSS incorporation, Chicago, Illinois, United States of America). The corresponding $\mathrm{P}$ value for each test was directly computed by the microprocessor, in which we used the one call test values:

Non - significant difference when $\mathrm{P}>0.05$.

Significant difference when $\mathrm{P} \leq 0.05$. rapidly centrifuged at $1000 \mathrm{rpm}$ for $20 \mathrm{~min}$

\section{Results}

As regarding to demographic characteristics of the studied group, there was no significant difference between both studied groups regarding age $(\mathrm{x}=0.574) \quad(\mathrm{p}=$ $0.449)$ and gender $(x=2.537)(p=0.663)$.

Clinical characteristics of patients' groups are demonstrated in (table 1) as regards to symptoms, onset, course, duration, number of lesion in each patient.

In our study the distribution of the studied cases according to site in group I: 25 $(40.0 \%)$ of the patients had lesions in the sole of the feet, $12(20.0 \%)$ of the patients had palmer lesion, $6(10 \%)$ of the patients had lesion on the dorsum of the hands, 6 $(11.7 \%)$ of the patients had facial lesions, 4 $(6.7 \%)$ of the patients had genital lesions and $1(1.7 \%)$ of the patients had lesions in multiple sites. Relations between IL 17 and different parameters in group I $(n=60)$ are demonstrated in mean IL-17 in group 1 was $(141.1 \pm 155.5 \mathrm{pg} / \mathrm{ml})$ while group 2 was $(49.97 \pm 22.36 \mathrm{pg} / \mathrm{ml})$ the difference was statistically significant $(\mathrm{p}<0.001)$. Group 1 showed significant increase in IL-17.

As regard to recurrence the mean IL 17 of negative cases was statistically higher 
$(178.88 \pm 176.32 \mathrm{pg} / \mathrm{ml})$ than those with positive recurrence $(65.42 \pm 46.95 \mathrm{pg} / \mathrm{ml})$.

Number and duration of the lesions showed a non-significant negative correlation with
IL $17(\mathrm{p}>0.05)$. Also table (2) showed that $44(73.3 \%)$ of the patients had no family history while $16(26.7 \%)$ of the patients had family history.

Table (1):Distribution of the studied cases according to different clinical parameters in group I $(n=60)$

\begin{tabular}{|c|c|c|}
\hline & No. & $\%$ \\
\hline \multicolumn{3}{|l|}{ Symptom } \\
\hline Skin lesion & 3 & 5.0 \\
\hline Painful - skin lesion & 57 & 95.0 \\
\hline Onset (Gradual) & 60 & 100.0 \\
\hline \multicolumn{3}{|l|}{ Course } \\
\hline Progressive & 46 & 76.7 \\
\hline Stationary & 14 & 23.3 \\
\hline \multicolumn{3}{|l|}{ Duration (months) } \\
\hline$<6$ & 18 & 30.0 \\
\hline $6-12$ & 40 & 66.7 \\
\hline$>12$ & 2 & 3.3 \\
\hline Range (months) & $1.0-18.0$ & \\
\hline Mean \pm SD. (months) & $7.77 \pm 3.21$ & \\
\hline Median (IQR) & $7.50(5.0-9.0)$ & \\
\hline \multicolumn{3}{|l|}{ Number } \\
\hline 1 & 10 & 16.7 \\
\hline$>1$ & 50 & 83.63 \\
\hline Min. - Max. & $1.0-10.0$ & \\
\hline Mean \pm SD. & $3.40 \pm 2.38$ & \\
\hline Median (IQR) & $3.0(2.0-4.0)$ & \\
\hline
\end{tabular}


Table (2): as regards significance of IL17 and recurrence history, duration of disease, number and family history .

\begin{tabular}{|c|c|c|c|c|}
\hline & $\mathbf{N}$ & $\begin{array}{l}\text { IL } 17 \\
\text { Mean } \pm \text { SD. }(\mathrm{pg} / \mathrm{ml})\end{array}$ & Test of sig. & $\mathbf{p}$ \\
\hline \multicolumn{5}{|c|}{ Recurrence } \\
\hline Negative & 40 & $178.88 \pm 176.32$ & \multirow{2}{*}{$\mathrm{U}=155.50 *$} & \multirow{2}{*}{$<0.001 *$} \\
\hline Positive & 20 & $65.42 \pm 46.95$ & & \\
\hline \multicolumn{5}{|c|}{ Duration (months) } \\
\hline$<6$ & 18 & $122.49 \pm 130.36$ & \multirow{3}{*}{$\begin{array}{l}\mathrm{H}= \\
1.112\end{array}$} & \multirow{3}{*}{0.574} \\
\hline $6-12$ & 40 & $150.83 \pm 169.85$ & & \\
\hline$>12$ & 2 & $112.65 \pm 15.34$ & & \\
\hline \multicolumn{5}{|l|}{ Number } \\
\hline 1 & 10 & $186.76 \pm 138.73$ & \multirow{2}{*}{$\begin{array}{l}\mathrm{U}= \\
53.0\end{array}$} & \multirow{2}{*}{0.080} \\
\hline$>1$ & 50 & $131.92 \pm 158.28$ & & \\
\hline \multicolumn{5}{|c|}{ Family history } \\
\hline Negative & 44 & $151.39 \pm 159.88$ & $\mathrm{U}=$ & \multirow{2}{*}{0.100} \\
\hline Positive & 16 & $112.65 \pm 143.55$ & 253.50 & \\
\hline
\end{tabular}

p: p value for association between IL17 (pg/ml) and with recurrence and family history

*: Statistically significant at $\mathrm{p} \leq 0.05$

U: Mann Whitney test H: H for Kruskal Wallis test

\section{Discussion}

Warts are very common benign tumours caused by HPV infection. HPV infection acquired from direct contact with an infected individual or from the environment. Warts are classified according to their appearance or site to different types like a verruca vulgaris verruca plana, plantar wart, and condyloma acuminatum (3).Regarding different types of lesions, the present study showed that out of the 60 patients, 24 of them (40\%) had plantar lesions. These findings came in line with another study which showed that the most common sites were hand $(47.3 \%)$ and feet $(41.8 \%)(6)$. 
Interleukin 17 (IL-17) is a pro-inflammatory cytokine involved in the control of many different disorders that include autoimmune, oncogenic, and many infectious diseases (7). $T$ cells that produce IL-17 arise as a specific population of CD4-positive T cells, which are called $\mathrm{T}$ helper 17 (Th17) cells that are distinct from the classic Th1 and Th2 cells ( 8). This study on the hand revealed that mean IL 17 in group I was (141.1 \pm $155.5 \mathrm{pg} / \mathrm{ml}$ ) while group II was $(49.97 \pm$ $22.36 \mathrm{pg} / \mathrm{ml})$. The difference was statistically significant $\left(\mathrm{p}<0.001^{*}\right)$. Group I showed a significant increase in mean IL 17 when compared to group 2.

In line with our findings Xue (9) reported that levels of IL-17 in high-risk HPV infection group $(15.11 \pm 6.744 \mathrm{pg} / \mathrm{ml})$ was slightly higher than in control group $(10.47 \pm 5.125 \mathrm{pg} / \mathrm{ml})$.

In Harmony with the current study Bonin (10) measured IL-17A in the sera and exfoliated cervical cells of high risk HPVinfected patients in comparison to control group . They observed that in HPV-positive patients, there was a significant increase in the concentration of IL-17 in the serum $(25.84 \pm 5.71 \mathrm{pg} / \mathrm{mL})$ when compared with that in exfoliated cervical cell samples (1.54 $\pm 0.42 \mathrm{pg} / \mathrm{mL})(\mathrm{p}<0.05)$. When compared to that in healthy patients, the concentration of II 17 was also higher in the serum from 99 \pm 1.800 versus $25.84 \quad \pm 5.71 \quad \mathrm{pg} / \mathrm{mL}$, respectively) $(\mathrm{p}<0.05)$.

Th17 cells have been associated with the rise of viral persistence and inhibition of $\mathrm{T}$ cell cytotoxity in the chronic viral infection model. This finding is due, in part, to the action of IL-17, as it was demonstrated that this cytokine interferes in the CD8+ $\mathrm{T}$ cell cytotoxic function by blocking the Fas-FasL pathway (11). In cases of persistent HPV infection associated with high levels of IL-17, this cytokine may be contributing to the greater survival of keratinocytes infected from the Fas-FasL pathway blocking, providing viral persistence. Another important point to be highlighted is the immunosuppression mediated by IL-17 in HPV-associated epithelial hyperplasia, as demonstrated by Gosmann (12). They suggested that blocking IL-17 could be of therapeutic use in persistent infection by high oncogenic risk HPV, which would help prevent the progression of premalignant lesions in cancer (12).

In contrary to our study there is a study done by ElHamed (4), in their study the mean serum level of IL-17 in patients with CW was significantly (P-value <.01) lower $(0.089$ $\mathrm{pg} / \mathrm{ml})$ than control group $(0.123 \mathrm{pg} / \mathrm{ml})$.

In contrary to the present study, a previous study (5) reported significant decrease in IL-17 level in patients with 
persistent warts when compared to controls. The mean serum level of IL-17 in patients with recalcitrant viral wart was $490 \mathrm{pg} / \mathrm{mL}$, while in the control group; it was $770 \mathrm{pg} / \mathrm{mL}$ with significant difference $(\mathrm{P}<.001)$.

The present study demonstrated high serum level of IL-17 in wart patient, In contrary to the previous two studies , and that may be explained with longer disease duration in the previous two studies leading to consumption of IL- 17 .

The present study demonstrated that 44 (73.3\%) of the patients had no family history while $16(26.7 \%)$ of the patients had positive family history of HPV.

In line with this study, another study (13) reported that family history of warts was observed in $27.7 \%$ of the cases, while, $72.3 \%$ of the patients had no family history.

The present study revealed significantly higher serum levels of IL-17 among patients with cutaneous warts when compared with the control group; this high serum levels of IL-17 could be considered as an important contributing immunological factors for increasing the risk of HPV infections and development in different cutaneous warts; however, this needs further verification on more comprehensive large-scale studies and to be more confirmed by further assessment of the lesional and non-lesional tissue required to investigate genetic polymorphism of IL-17 genes .

\section{References}

1. Lacarrubba, F., Verzì, A. E., Quattrocchi, E., \&Micali, G. (2018). Cutaneous and Anogenital Warts. In Atlas of Pediatric Dermatoscopy (pp. 3544). Springer, Cham.

2. Xu, S., \& Cao, X. (2010). Interleukin-17 and its expanding biological functions.Cellular \& molecular immunology, 7(3), 164.

3. Zhu, S., \&Qian, Y. (2012). IL-17/IL-17 receptor system in autoimmune disease: mechanisms and therapeutic potential. Clinical science, 122(11), 487-511.

4. Lynch MD, Cliffe J, Morris-Jones R. Management of cutaneous viral warts. BMJ. 2014;27:348.

5. El-Hamd MA, Assaf HA, Nada EA. Possible role of interleukin 17 and macrophage migration inhibitory factor in cutaneous warts. J Cosmetic Dermatol. 2017;17(6):1250-1253.

6. Ghanem AH, Abdulla Mohamed Esawy, Naglaa Ali Khalifa, Hend Mahmoud Kamal, 2019: Evaluation of serum interleukin 17 and zinc levels in recalcitrant viral wart, First published: 14 August 2019, https://doi.org/10.1111/jocd.13106

7. Öztekin, C., Öztekin, A., Taştan, K., Özmen, G. G., \& Demir Pektaş, S. (2018). The association between verruca vulgaris and Vitamin D: Is there a casual link?.

8. Chamoun MN, Blumenthal A, Sullivan MJ, Schembri MA, Ulett GC. Bacterial pathogenesis and interleukin-17: interconnecting mechanisms of immune regulation, host genetics, and microbial virulence that influence severity of infection. Crit Rev Microbiol. 2018;44(4):465-486.

9. Steinman L. A. brief history of $\mathrm{T} \mathrm{H} \mathrm{17,} \mathrm{the} \mathrm{first}$ major revision in the $\mathrm{T} \mathrm{H} 1 / \mathrm{T} \mathrm{H} 2$ hypothesis of $\mathrm{T}$ cell-mediated tissue damage. Nat Med. 2007;13(2):139. 
10.Xue, J., Wang, Y., Chen, C., Zhu, X., Zhu, H., \& Hu, Y. (2018). Effects of Th17 cells and IL-17 in the progression of cervical carcinogenesis with high-risk human papillomavirus infection. Cancer medicine, 7(2), 297-306.

11.C.M. Bonin, L.Z. Almeida-Lugo, A.R. dos Santos, C.T. Padovani , A.F. Pina, A.M. Ferreira, et al Interleukin-17 expression in the serum and exfoliated cervical cells of patients infected with high-risk oncogenic human papillomavirus. Cytokine, $\quad$ 120, 92-98. doi:10.1016/j.cyto.2019.04.008
12.W. Hou, H.S. Kang, B.S. Kim, TH17cells enhance viral persistence and inhibit tcell cytotoxicity in a model of chronic virus infection,J.Exp.Med.206(2009)313-328.

13.C. Gosmann, S.R. Mattarollo, J.S. Bridge, I.H. Frazer, A. Blumenthal, IL-17suppresses immune effector functions in human papillomavirusassociated epithelial hyperplasia,J. Immunol. 193 (2014) 2248-2257.

14.Laxmisha C, Devinder Mohan Thappa, Telanseri J Jaisankar, Viral Warts-A Clinico-Epidemiological Study, Year : $2003: 48: 3: 142-145$

To cite this article: Osama H. Alkady, Soha E. Abduulah, Yasser M. Ismail, Shymaa M. Rezk. Evaluation of Interleukin-17 in Viral Warts. BMFJ 2021; 38(1): 94-101. DOI: $10.21608 / \mathrm{bmfj} .2020 .41415 .1313$ 